\title{
NEGATIVE PRESSURE RESPIRATION, WATER DIURESIS AND NATRIURESIS IN NORMOTENSIVE, HYPERTENSIVE AND PREHYDRATED NORMOTENSIVE SUBJECTS *
}

\author{
By WILLIAM H. HULET AND HOMER W. SMITH
}

(From the Department of Physiology, New York University College of Medicine, N. Y.)

(Submitted for publication June 3, 1959; accepted July 23, 1959)

Sieker, Gauer and Henry (1), examining normotensive subjects, have demonstrated that breathing against continuous negative pressure elicits a moderate water diuresis, believed to be mediated by stretch receptors in the left atrium and reflex inhibition of the secretion of the antidiuretic hormone. This water diuresis, which has been confirmed by others (2-4) is not accompanied in normotensive subjects by any noteworthy increase in the excretion of sodium. On the other hand, the lability of sodium excretion in subjects with essential hypertension is well known. Effective natriuretic stimuli include urethral catheterization (5) and the infusion of mannitol (6), saline (7$11)$ or glucose and the ingestion of water or beer (12). It therefore seemed of interest to determine whether or not negative pressure breathing produces natriuresis in hypertensive subjects; and since, as Ladd (13) has shown, massive prehydration of normotensive subjects predisposes to excessive natriuresis and water diuresis during subsequent saline infusion, it was of equal interest to determine how prehydrated subjects would react to negative pressure breathing.

\section{METHODS}

Thirty-two observations have been made on 31 subjects, eight males and 23 females, ranging in age from 19 to 59 years, selected from the wards and Hypertension Clinic of the Third (New York University) Medical Division of Bellevue Hospital. Essential hypertension (without evidence of circulatory failure or advanced renal impairment) was present in 11 subjects; the remaining 20 were normotensive and free of cardiovascular renal disease. All were maintained on the regular hospital diet except five hypertensive subjects from the outpatient clinic who received a home diet unrestricted in respect to sodium intake.

Negative pressure breathing (NPB) of room air was

* Aided by a grant (H-1172) from the National Heart Institute of the National Institutes of Health, Bethesda, Md. accomplished by means of a standard mouthpiece and nasal clamp, and respiration to and from an $80 \mathrm{~L}$. reinforced polyethylene cylinder (garbage container) which: was partially evacuated by a high flow vacuum cleaner. The pressure was maintained close to $-15 \mathrm{~cm}$. water, as measured with a water manometer, by adjustment of an air intake valve. All subjects were instructed in the mechanics of the test beforehand and assured that it was. harmless. Negative pressure of $-15 \mathrm{~cm}$. water proved tolerable for all subjects, but in four subjects a pressure of $-25 \mathrm{~cm}$. water proved to be intolerable because of the effort required.

Previous investigators have studied subjects who were moderately hydrated, but because of the lability of sodium excretion in hypertensive subjects we have avoided both water and saline and carried out our observations in the hydropenic state attained by 12 to 15 hours' abstinence from fluids. Because of this circumstance, urine was collected by catheter, with the utmost care with respect to emptying the bladder and expulsion of residual urine by means of air. Special precautions were taken to have the basal urine flow at as constant a level as possible.

In both control and hypertensive subjects, the test was started at 8:00 a.m., after a one to two hour ambulatory period. With the subject in a supine position (one pillow), the bladder was catheterized, emptied and the catheter left in place. One to two hours more were allowed to elapse after catheterization to avoid postural diuresis. At this time the urine flow had become fairly constant, as judged by the fact that in three ensuing quantitative urine collection periods of 15 minutes each (hereafter designated as basal) the rate of flow in two successive periods did not differ, at most, by more than 25 per cent. NPB was started at the end of the third basal collection and continued for 30 minutes; a fourth urine sample was collected at the end of 15 minutes without interruption of NPB, and a fifth immediately after the cessation of NPB. Venous blood samples were drawn at the beginning and end of the basal collection periods, shortly after the cessation of NPB and again at the end of the test. Urine was preserved in stoppered Lusteroid tubes and blood was centrifuged at once and the plasma stored in stoppered tubes. Heparin, two drops per $15 \mathrm{ml}$. of blood, was used as an anticoagulant.

The preparatory protocol for prehydrated subjects differed necessarily from that described above. They were taken off fluids 12 to 15 hours before coming to the Research Unit at 8:00 a.m. Here they drank $2 \mathrm{~L}$. of tap. 
water in the course of 20 to 40 minutes and remained ambulatory thereafter for five to six hours, after which they assumed the supine position and were catheterized. They were allowed to eat a chocolate bar during the ambulatory period, but no fluids were permitted after prehydration. The first basal urine collection period was begun after two to three hours in the supine position when the urine flow had become fairly constant, and well after the last phase of the water diuresis and presumably beyond the end of any postural diuresis. After three urine collection periods of 15 minutest each, NPB was instituted (some eight to nine hours after water loading) for 30 minutes as described above, followed by three post-NPB urine collection periods.

Osmolality of plasma and urine was determined by means of a Johlin freezing point apparatus (14) and the thermistor and bridge-null-point-detector unit of Bowman, Trantham and Caulfield (15). Sodium was determined by flame photometry, employing lithium as an internal standard. Inulin clearances were avoided because even a small infusion may elicit natriuresis in hypertensive subjects (10).

Because the water diuresis induced by NPB is transient, we have arbitrarily chosen as representing the maximal response to NPB that urine period which showed the greatest value of $\mathrm{V}$; this was either the last period of NPB or the period immediately following. In half the subjects of each group, urine flow was maximal in the last period of NPB and in the remaining half, urine flow was maximal in the period immediately following NPB, but in either case this is the period designated NPB in Tables I, II and III.

Values for urine volume (V), sodium excretion $\left(\mathrm{U}_{\mathrm{Na}} \mathrm{V}\right)$, total solute excretion ( $\mathrm{U}_{\text {osm } \mathrm{m}} \mathrm{V}$ ), osmolal clearance $\left(\mathrm{C}_{\mathrm{os} m}\right)$ and free water clearance $\left(\mathrm{C}_{\mathrm{H}_{2} \mathrm{O}}\right)$, observed during (or immediately after) NPB have been compared with basal values in each subject by Wilcoxon's signed-rank test for matched pairs $(16,17)$, a nonparametric method of statistical analysis. Nonparametric analysis seemed more appropriate than the parametric method (which employs the mean and standard deviation) because it can be applied to small samples which may not have a Gaussian distribution, and its sensitivity is nearly as great as that of the " $\mathrm{t}$ " test, applied to samples with a Gaussian distribution which a priori assumes independent variation among the variables under consideration. However, for comparison the same data have been analyzed by the parametric method (16), and

TABLE I

Normal hydropenic subjects: Response to negative pressure breathing*

\begin{tabular}{|c|c|c|c|c|c|c|c|c|c|c|c|}
\hline Subject & $\begin{array}{c}\text { Body } \\
\text { surface } \\
\text { area }\end{array}$ & Procedure & V & $\mathrm{U}_{\mathrm{Na}}$ & $\mathrm{UNaV}_{\mathrm{Na}}$ & $\mathrm{U}_{\text {osm }}$ & $\mathrm{U}_{\mathrm{osm}} \mathrm{V}$ & Cosm & $\mathrm{C}_{\mathrm{H}_{2} \mathrm{O}}$ & $\mathrm{P}_{\mathrm{Na}}$ & $P_{\text {osm }}$ \\
\hline & $M .{ }^{2}$ & & $\operatorname{ml} . / \min$ & $m E q . / L$ & $\underset{\text { min. }}{\mu E q . /}$ & $\underset{\mathrm{Kg} . \mathrm{H}_{2} \mathrm{O}}{\mathrm{mOsm} . /}$ & $\mu O s m . / m i n$ & ml./min. & $m l . / m i n$ & $m E q . / L$ & $\underset{\mathrm{Kg.} \mathrm{H}_{2} \mathrm{O}}{\mathrm{mOsm./}}$ \\
\hline \multirow[t]{3}{*}{ R.R.† } & 1.35 & B & 3.02 & 37 & 112 & 129 & 389 & 1.38 & 1.64 & 141 & 281 \\
\hline & & NPB & 5.63 & 44 & 248 & 101 & 569 & 2.04 & 3.59 & 141 & 279 \\
\hline & & p-NPB & 1.77 & 98 & 173 & 240 & 425 & 1.52 & 0.25 & 142 & 279 \\
\hline \multirow[t]{3}{*}{ R.P. } & 1.75 & & 1.78 & 127 & 226 & 686 & 1,220 & 4.02 & -2.24 & 144 & 306 \\
\hline & & NPB & 1.27 & 126 & 160 & 644 & 819 & 2.68 & -1.41 & 145 & 306 \\
\hline & & p-NPB & 0.80 & 167 & 134 & 777 & 622 & 2.03 & -1.23 & 148 & 306 \\
\hline \multirow[t]{2}{*}{ V.H. } & 1.60 & B & 0.80 & 100 & 80 & 639 & 508 & 1.77 & $\begin{array}{r}-0.97 \\
-0.28\end{array}$ & 142 & 289 \\
\hline & & p-NPB & $\begin{array}{l}2.20 \\
1.23\end{array}$ & $\begin{array}{l}55 \\
94\end{array}$ & $\begin{array}{l}121 \\
116\end{array}$ & $\begin{array}{l}330 \\
485\end{array}$ & $\begin{array}{l}728 \\
596\end{array}$ & $\begin{array}{l}2.48 \\
2.04\end{array}$ & $\begin{array}{l}-0.28 \\
-0.81\end{array}$ & $\begin{array}{l}143 \\
145\end{array}$ & $\begin{array}{l}293 \\
293\end{array}$ \\
\hline \multirow[t]{3}{*}{ C.S. } & 1.62 & B & 0.44 & $\begin{array}{r}94 \\
112\end{array}$ & 50 & $\begin{array}{l}403 \\
686\end{array}$ & 304 & $\begin{array}{l}2.04 \\
1.05\end{array}$ & $\begin{array}{l}-0.01 \\
-0.60\end{array}$ & $\begin{array}{l}143 \\
139\end{array}$ & $\begin{array}{l}293 \\
291\end{array}$ \\
\hline & & NPB & 1.28 & 109 & 139 & 540 & 691 & 2.41 & -1.13 & 137 & 287 \\
\hline & & p-NPB & 0.93 & 140 & 130 & 638 & 595 & 2.09 & -1.15 & 134 & 285 \\
\hline \multirow[t]{3}{*}{ E.M. } & 1.55 & B & 1.66 & 168 & 278 & 670 & 1,110 & 4.05 & -2.39 & 134 & 274 \\
\hline & & NPB & 4.03 & 68 & 274 & 250 & 1,010 & 3.64 & 0.39 & 134 & 277 \\
\hline & & p-NPB & 2.13 & 106 & 226 & 381 & 811 & 2.95 & -0.82 & 134 & 275 \\
\hline \multirow[t]{3}{*}{ V.D. } & 1.50 & B & 1.52 & 97 & 147 & 465 & 706 & 2.52 & -1.00 & 130 & 280 \\
\hline & & NPB & 2.37 & 97 & 230 & 420 & 996 & 3.50 & -1.13 & 132 & 285 \\
\hline & & p-NPB & 1.60 & 121 & 194 & 540 & 865 & 3.03 & -1.43 & 134 & 285 \\
\hline \multirow[t]{3}{*}{ I.D. } & 1.75 & B & 0.64 & 155 & 100 & 788 & 507 & 1.84 & -1.20 & 130 & 276 \\
\hline & & NPB & 1.59 & 161 & 256 & 700 & 1,110 & 4.04 & -2.45 & 131 & 276 \\
\hline & & p-NPB & 0.95 & 185 & 175 & 720 & 681 & 2.47 & -1.52 & 130 & 276 \\
\hline \multirow[t]{3}{*}{ E.B. } & 1.41 & B & 2.09 & 78 & 162 & 300 & 628 & 2.16 & -0.07 & 142 & 291 \\
\hline & & NPB & 4.23 & 48 & 203 & 210 & 888 & 3.05 & 1.18 & 142 & 291 \\
\hline & & p-NPB & 1.35 & 167 & 226 & 520 & 704 & 2.42 & -1.07 & 142 & 291 \\
\hline \multirow[t]{3}{*}{ M.P. } & 1.50 & & 0.98 & 308 & 301 & 838 & 817 & 2.84 & -1.86 & 140 & 288 \\
\hline & & NPB & 1.09 & 320 & 349 & 832 & 908 & 3.14 & -2.05 & 138 & 289 \\
\hline & & p-NPB & 0.23 & 337 & 78 & 864 & 201 & 0.69 & -0.46 & 136 & 291 \\
\hline \multirow[t]{3}{*}{ B.H. } & 1.42 & & 2.29 & 69 & 158 & 284 & 651 & 2.28 & 0.01 & 141 & 285 \\
\hline & & NPB & 2.10 & 66 & 139 & 294 & 617 & 2.14 & -0.04 & 141 & 288 \\
\hline & & $\mathrm{p}-\mathrm{NPB}$ & 0.55 & 262 & 145 & 888 & 491 & 1.69 & -1.14 & 141 & 290 \\
\hline
\end{tabular}

${ }^{*} \mathrm{~B}=$ average of three basal periods $; \mathrm{NPB}=$ negative pressure breathing $; \mathrm{p}-\mathrm{NPB}=$ post negative pressure breathing $\uparrow$ Surreptitious water ingestion prior to the test could not be excluded. 
TABLE II

Hypertensive hydropenic patients: Response to negative pressure breathing*

\begin{tabular}{|c|c|c|c|c|c|c|c|c|c|c|c|}
\hline Subject & $\begin{array}{c}\text { Body } \\
\text { surface } \\
\text { area }\end{array}$ & Procedure & $\mathrm{V}$ & $\mathrm{U}_{\mathrm{Na}}$ & $\mathrm{U}_{\mathrm{NaV}}$ & $\mathrm{U}_{\mathrm{osm}}$ & $\mathrm{U}_{\mathrm{osm}} \mathrm{V}$ & Cosm & $\mathrm{C}_{\mathrm{H}_{2} \mathrm{O}}$ & $\mathrm{P}_{\mathrm{Na}}$ & $P_{\text {osm }}$ \\
\hline & $M . .^{2}$ & & ml./min & $m E q . / L$ & $\underset{\text { min. }}{\mu E q . /}$ & $\underset{\mathrm{Kg} . \mathrm{H}_{2} \mathrm{O}}{\operatorname{mosm} /}$ & $\mu O s m . / \min$. & ml. $/ \min$ & ml./min. & $m E q . / L$ & $\begin{array}{l}m \mathrm{~m} s m . / \\
\mathrm{Kg} . \mathrm{H}\end{array}$ \\
\hline \multirow[t]{3}{*}{ S.K. } & 1.69 & B & 0.66 & 155 & 102 & 716 & 472 & 1.64 & -0.98 & 140 & 288 \\
\hline & & NPB & 0.73 & 148 & 107 & 700 & 509 & 1.78 & -1.05 & 140 & 286 \\
\hline & & p-NPB & 0.80 & 149 & 119 & 688 & 550 & 1.91 & -1.11 & 140 & 288 \\
\hline \multirow[t]{3}{*}{ M.S. } & 1.35 & & 1.42 & 175 & 248 & 606 & 862 & 3.08 & -1.66 & 142 & 280 \\
\hline & & NPB & 6.60 & 44 & 290 & 130 & 858 & 3.06 & 3.54 & 140 & 281 \\
\hline & & p-NPB & 2.87 & 86 & 247 & 355 & 1,020 & 3.62 & -0.75 & 143 & 281 \\
\hline \multirow[t]{3}{*}{ H.W. } & 1.89 & & 3.71 & 150 & 558 & 401 & 1,487 & 5.32 & -1.61 & 142 & 280 \\
\hline & & NPB & 7.47 & 106 & 792 & 256 & 1,910 & 6.93 & 0.54 & 142 & 276 \\
\hline & & p-NPB & 4.13 & 168 & 694 & 382 & 1,570 & 5.75 & -1.62 & 142 & 274 \\
\hline \multirow[t]{3}{*}{ W.K. } & 1.92 & & 0.86 & 254 & 218 & 750 & 643 & 2.25 & -1.39 & 142 & 285 \\
\hline & & NPB & 1.40 & 132 & 185 & 408 & 572 & 2.05 & -0.65 & 142 & 279 \\
\hline & & p-NPB & 0.63 & 286 & 180 & 798 & 501 & 1.78 & -1.15 & 143 & 281 \\
\hline \multirow[t]{3}{*}{ W.R. } & 1.91 & B & 0.74 & 136 & 100 & 650 & 481 & 1.65 & -1.00 & 140 & 291 \\
\hline & & NPB & 0.75 & 117 & 90 & 633 & 478 & 1.64 & -0.89 & 142 & 291 \\
\hline & & p-NPB & 0.61 & 118 & 72 & 642 & 394 & 1.35 & -0.74 & 143 & 291 \\
\hline \multirow[t]{3}{*}{ D.W. } & 1.78 & B & 1.75 & 122 & 213 & 590 & 1,932 & 3.44 & -1.69 & 137 & 300 \\
\hline & & NPB & 4.60 & 105 & 483 & 405 & 1,790 & 5.97 & -1.37 & 137 & 300 \\
\hline & & p-NPB & 1.80 & 108 & 194 & 444 & 800 & 2.67 & -0.87 & 137 & 300 \\
\hline \multirow[t]{3}{*}{ S.T. } & 1.55 & & 0.52 & 184 & 96 & 700 & 364 & 1.35 & -0.83 & 142 & 270 \\
\hline & & NPB & 1.16 & 197 & 228 & 742 & 860 & 3.15 & -1.99 & 142 & 273 \\
\hline & & p-NPB & 1.00 & 123 & 123 & 600 & 600 & 2.20 & -1.20 & 142 & 273 \\
\hline \multirow[t]{3}{*}{ E.C. } & 1.86 & & 1.22 & 53 & 65 & 360 & 439 & 1.51 & -0.29 & 142 & 291 \\
\hline & & NPB & 3.50 & 69 & 242 & 249 & 871 & 3.00 & 0.50 & 142 & 290 \\
\hline & & p-NPB & 0.76 & 64 & 49 & 396 & 301 & 1.04 & -0.28 & 142 & 288 \\
\hline \multirow[t]{3}{*}{ D.M. } & 1.67 & & 0.56 & 212 & 119 & 875 & 490 & 1.76 & -1.20 & 142 & 278 \\
\hline & & NPB & 0.88 & 180 & 158 & 784 & 689 & 2.49 & -1.61 & 144 & 277 \\
\hline & & p-NPB & 0.71 & 205 & 145 & 856 & 606 & 2.18 & -1.47 & 143 & 278 \\
\hline \multirow[t]{3}{*}{ E.B. } & 1.70 & & 1.22 & 50 & 61 & 468 & 571 & 1.92 & -0.70 & 144 & 297 \\
\hline & & NPB & 1.15 & 54 & 62 & 490 & 564 & 1.90 & -0.75 & 144 & 297 \\
\hline & & $\mathrm{p}-\mathrm{NPB}$ & 0.49 & 31 & 15 & 594 & 292 & 0.99 & -0.49 & 144 & 297 \\
\hline
\end{tabular}

${ }^{*} \mathrm{~B}=$ average of three basal periods $; \mathrm{NPB}=$ negative pressure breathing; $\mathrm{p}-\mathrm{NPB}=$ post negative pressure breathing.

the probability (p) values of significance, as determined by the simpler nonparametric test, have in all instances been associated with analogous values of significance as obtained by the " $t$ " test of parametric analysis.

\section{RESULTS AND DISCUSSION}

In opening this discussion it must be re-emphasized, first, that where others have examined the effects of NPB in moderately (and variably) hydrated subjects, ${ }^{1}$ we have endeavored to bring our subjects into a fairly steady hydropenic state, for the reason that we were interested less in evoking a substantial water diuresis than in examining the effects of NPB on natriuresis in hypertensive and prehydrated subjects; the former

1 Sieker, Gauer and Henry (1) gave a priming dose of $300 \mathrm{ml}$. of 0.14 per cent $\mathrm{NaCl}$ and 50 to $100 \mathrm{ml}$. every half hour; Surtshin, Hoeltzenbein and White (2) gave $300 \mathrm{ml}$. of 0.14 per cent $\mathrm{NaCl}$; Boylan and Antkowiak (3) gave 50 to $150 \mathrm{ml}$. of water every half hour; and Murdaugh, Sieker and Manfredi (4) gave one glass of water every two hours for six hours prior to the study. are known to give exaggerated natriuresis to water (12), while the natriuretic response of prehydrated subjects appears to be inhibited by rehydration (13). From the studies of others and from our own results, it is clear that NPB has at best a very mild diuretic effect, and in retrospect it is perhaps surprising that we obtained as distinct a diuretic effect in hydropenia as we did.

Second, under the oliguric conditions of our observations, all constituents of the urine are present in a relatively concentrated state and any abrupt increase in urine flow, consequent to an increased excretion of free water, will lead to a substantial dead space error as concentrated urine, formed at a pre-existing low flow, is pushed out of the collecting ducts, pelvis and ureters at an accelerated rate.

Third, an increase in urine flow at oliguric levels will be accompanied by a substantial increase in excretion of urea and hence in $\mathrm{U}_{\mathrm{osm}} \mathrm{V}$, a result which is incidental rather than specifically related 
to NPB. However, we have not followed urea excretion in these studies. ${ }^{2}$

Lastly, in hydropenia the urine is of course hyperosmotic to the blood; in previous discussions (18-20), the water abstracted in attaining this hyperosmotic state has been designated as $\mathrm{T}^{\mathbf{c}}{ }_{\mathbf{H}_{2} \mathbf{O}}$, and calculated as

$$
\mathrm{T}_{\mathrm{H}_{2} \mathrm{O}}=\mathrm{C}_{\mathrm{osm}}-\mathrm{V} \text {. }
$$

However, except for sign, a decrease in $\mathrm{T}^{\mathrm{c}} \mathrm{H}_{2} \mathrm{O}$ is mathematically (and physiologically) indistinguishable from an increase in free water clearance,

${ }^{2} \mathrm{An}$ increase in $\mathrm{U}_{\text {osm } m} \mathrm{~V}$ (and consequently $\mathrm{C}_{\text {osm }}$ ) due to "washout" of urea solely as a result of increased urine flow would tend to mask a portion of the actual free water excretion that occurred in response to NPB. Therefore, actual values for free water clearance $\left(\mathrm{C}_{\mathrm{H}_{2} \mathrm{O}}\right)$ are possibly higher than those calculated. calculated as

$$
\mathrm{C}_{\mathrm{H}_{2} \mathrm{O}}=\mathrm{V}-\mathrm{C}_{\mathrm{osm}} \text {. }
$$

Since an obvious inconvenience attaches to a recurring change in designation from $\mathrm{T}^{\mathrm{c}} \mathrm{H}_{2} \mathrm{O}$ to $\mathrm{C}_{\mathrm{H}_{2} \mathrm{O}}$ as the urine passes from the hyperosmotic to the hypo-osmotic state (and vice versa), we have adhered to the latter equation and simply recorded negative and positive values for $\mathrm{C}_{\mathrm{H}_{2} \mathrm{O}}$. Whatever semantic difficulties may be raised by talking about a "negative renal clearance," terminology seems to be evolving in this direction in the writings of others, and the advantages of a uniform method of expression in our immediate study are obvious.

\section{Control subjects}

Table I gives our observations on 10 control normotensive subjects. The basal values repre-

TABLE III

\begin{tabular}{|c|c|c|c|c|c|c|c|c|c|c|c|}
\hline Subject & $\begin{array}{c}\text { Body } \\
\text { surface } \\
\text { area }\end{array}$ & Procedure & V & $\mathrm{U}_{\mathrm{NS}}$ & $\mathrm{UNaV}_{\mathrm{Na}}$ & $\mathrm{U}_{\mathrm{osm}}$ & $\mathrm{U}_{\mathrm{osm}} \mathrm{V}$ & Cosm & $\mathrm{C}_{\mathrm{H}_{2} \mathrm{O}}$ & $\mathrm{P}_{\mathrm{Na}}$ & Posm \\
\hline & $M .{ }^{2}$ & & $\operatorname{ml} . / \min$ & $m E q . / L$ & $\underset{\text { min. }}{\mu E q . /}$ & $\underset{\mathrm{Kg} . \mathrm{H}}{\mathrm{mO}} \mathrm{O}$ & $\mu O s m . / \min$. & ml./min & $\operatorname{ml} . / \min$ & $m E q . / L$ & $\begin{array}{l}m \mathrm{O} \text { sm./ } \\
\mathrm{Kg} . \mathrm{H}_{2} \mathrm{O}\end{array}$ \\
\hline \multirow[t]{3}{*}{ P.R. } & 1.80 & \multirow{33}{*}{$\begin{array}{l}\text { B } \\
\text { NPB } \\
\text { p-NPB } \\
\text { B } \\
\text { NPB } \\
\text { p-NPB } \\
\text { B } \\
\text { NPB } \\
\text { p-NPB } \\
\text { B } \\
\text { NPB } \\
\text { p-NPB } \\
\text { B } \\
\text { NPB } \\
\text { p-NPB } \\
\text { B } \\
\text { NPB } \\
\text { p-NPB } \\
\text { B } \\
\text { NPB } \\
\text { p-NPB } \\
\text { B } \\
\text { NPB } \\
\text { p-NPB } \\
\text { B } \\
\text { NPB } \\
\text { p-NPB } \\
\text { B } \\
\text { NPB } \\
\text { p-NPB } \\
:\end{array}$} & 2.26 & 45 & 101 & 300 & 678 & 2.30 & -0.04 & 138 & 294 \\
\hline & & & 5.47 & 49 & 268 & 222 & 1,210 & 4.09 & 1.38 & 139 & 297 \\
\hline & & & 0.64 & 176 & 112 & 872 & 557 & 1.86 & -1.22 & 140 & 300 \\
\hline R.S. & 1.75 & & 1.13 & 68 & 76 & 391 & 442 & 1.58 & -0.45 & 139 & 279 \\
\hline & & & 2.83 & 40 & 113 & 162 & 458 & 1.63 & 1.20 & 139 & 281 \\
\hline & & & 0.73 & 183 & 134 & 721 & 529 & 1.88 & -1.15 & 139 & 282 \\
\hline L.B. & 1.45 & & 1.35 & 146 & 197 & 582 & 786 & 2.88 & -1.53 & 143 & 273 \\
\hline & & & $\begin{array}{l}8.93 \\
1.20\end{array}$ & $\begin{array}{r}32 \\
220\end{array}$ & $\begin{array}{l}286 \\
264\end{array}$ & $\begin{array}{l}102 \\
707\end{array}$ & $\begin{array}{l}910 \\
849\end{array}$ & $\begin{array}{l}3.34 \\
3.10\end{array}$ & $\begin{array}{r}5.59 \\
-1.90\end{array}$ & $\begin{array}{l}143 \\
143\end{array}$ & $\begin{array}{l}273 \\
274\end{array}$ \\
\hline K.P. & 2.08 & & 2.99 & 59 & 177 & 286 & 856 & 3.04 & -0.05 & 131 & 282 \\
\hline & & & 6.60 & 42 & 277 & 172 & 1,130 & 4.03 & 2.57 & 131 & 282 \\
\hline & & & 0.84 & 218 & 183 & 1,048 & 880 & 3.12 & -2.28 & 131 & 282 \\
\hline J.B. & 1.35 & & 0.62 & 138 & 86 & 591 & 368 & 1.32 & -0.70 & 140 & 279 \\
\hline & & & 2.47 & 70 & 173 & 214 & 528 & 1.87 & 0.60 & 141 & 283 \\
\hline & & & 0.47 & 225 & 105 & 707 & 330 & 1.16 & -0.69 & 142 & 285 \\
\hline E.D. & 1.75 & & 2.43 & 76 & 185 & 304 & 740 & 2.66 & -0.23 & 142 & 278 \\
\hline & & & 4.20 & 52 & 218 & 202 & 849 & 3.04 & 1.16 & 142 & 279 \\
\hline & & & 0.93 & 140 & 131 & 576 & 537 & 1.92 & -0.99 & 142 & 279 \\
\hline L.J. & 1.70 & & 1.24 & 69 & 86 & 538 & 667 & 2.34 & -1.10 & 141 & 285 \\
\hline & & & 1.80 & 63 & 113 & 388 & 699 & 2.45 & -0.65 & 139 & 285 \\
\hline & & & 0.77 & 145 & 111 & 780 & 598 & 2.10 & -1.33 & 140 & 285 \\
\hline A.B. & 1.73 & & 1.07 & 208 & 223 & 751 & 804 & 2.79 & -1.72 & 143 & 288 \\
\hline & & & 1.49 & 200 & 298 & 678 & 1,010 & 3.47 & -1.98 & 143 & 291 \\
\hline & & & 0.96 & 290 & 278 & 952 & 914 & 3.12 & -2.16 & 143 & 293 \\
\hline G.D. & 1.57 & & 2.23 & 56 & 124 & 205 & 458 & 1.61 & 0.62 & 142 & 285 \\
\hline & & & 3.95 & 45 & 182 & 176 & 706 & 2.45 & 1.50 & 140 & 288 \\
\hline & & & 0.60 & 158 & 95 & 595 & 357 & 1.20 & -0.60 & 138 & 297 \\
\hline S.B. & 1.62 & & 1.01 & 86 & 87 & 469 & 474 & 1.69 & -0.68 & 145 & 281 \\
\hline & & & 2.53 & 86 & 218 & 309 & 782 & 2.72 & -0.19 & 142 & 288 \\
\hline & & & 1.20 & 110 & 132 & 388 & 466 & 1.62 & -0.42 & 142 & 288 \\
\hline \multirow{4}{*}{\multicolumn{2}{|c|}{$\begin{array}{l}\text { Avg. basal values: } \\
\text { Controls } \\
\text { Hypertensives } \\
\text { Prehydrated }\end{array}$}} & & & & & & & & & & \\
\hline & & & 1.52 & & 161 & & 684 & 2.39 & -0.87 & 138 & 286 \\
\hline & & & 1.26 & & 178 & & 684 & 2.39 & -1.13 & 141 & 286 \\
\hline & & & 1.63 & & 134 & & 627 & 2.22 & -0.60 & 140 & 282 \\
\hline
\end{tabular}

Normal prehydrated subjects: Response to negative pressure breathing*

${ }^{*} \mathrm{~B}=$ average of three basal periods; $\mathrm{NPB}=$ negative pressure breathing; $\mathrm{p}-\mathrm{NPB}=$ post negative pressure breathing. 
sent the averages of three 15 minute urine collections prior to NPB. That a fairly steady rate of urine flow had been attained by our protocol is shown by the fact that $\mathrm{V}$ for all 30 basal periods averaged $1.52 \mathrm{ml}$. per minute, while the 10 periods immediately preceding NPB averaged $1.47 \mathrm{ml}$. per minute. Eight subjects responded to NPB by an increase in V. In three subjects (R.R., E.M. and E.B.) $\mathrm{C}_{\mathrm{H}_{2} \mathrm{O}}$ was positive and in one subject, (V.H.), the change in $\mathrm{C}_{\mathrm{H}_{2} \mathrm{O}}$ was directionally positive. The change to a more negative $\mathrm{C}_{\mathrm{H}_{2} \mathrm{O}}$ in Subjects C.S. and I.D. may reflect a falsely high $\mathrm{C}_{\text {osm }}$, the consequence of "washout" of urea, which conceivably could obscure a directionally positive $\mathrm{C}_{\mathrm{H}_{2} \mathrm{O}}$. The difference between the average values of $\mathrm{C}_{\mathrm{H}_{2} \mathrm{O}}$ for all 10 subjects, as between the basal and NPB periods $(-0.87$ and $-0.33 \mathrm{ml}$. per minute, respectively), was not statistically significant, but this is not surprising since many uncontrollable factors can influence water diuresis of small magnitude, such as differences in psychic reaction, duration and degree of hydropenia and so forth. Moreover, it is possible that some persons are insensitive to NPB-Boylan and Antkowiak (3) report failure to obtain water diuresis in four out of 16 moderately hydrated subjects. Consequently the fact that the mean value of $\mathrm{C}_{\mathrm{H}_{2} \mathrm{O}}$ did not increase significantly in our hydropenic subjects is less important than the qualitative fact that four out of our 10 subjects gave an absolute or directionally positive change in $\mathrm{C}_{\mathrm{H}_{2} \mathrm{O}} .^{3}$

With respect to sodium excretion, the basal values of $\mathrm{U}_{\mathrm{Na}} \mathrm{V}$ varied widely (50 to $301 \mu \mathrm{Eq}$. per minute), which is not unexpected in view of the well known variability of this term. Nevertheless our protocol achieved a steady state in

\footnotetext{
3 The average change in $\mathrm{V}(+1.06 \mathrm{ml}$. per minute) associated with NPB is statistically significant $(p<0.05)$; but the changes in the component terms, $C_{\text {osm }}(+0.52 \mathrm{ml}$. per minute) and $\mathrm{C}_{\mathrm{H}_{2} \mathrm{O}}(+0.54 \mathrm{ml}$. per minute $)$, are not individually significant $(p>0.05$ in both instances). This illustrates one of the ambiguities of statistical analysis: two variables, neither of which alone varies by a significant amount, can, when added apparently in a random manner, yield a sum which in the average does vary by a significant amount. Hence the futility of trying to prove, by statistical analysis alone, that a compound variable differs, as between two experimental conditions, by a physiologically significant amount. The converse argument is, of course, not true: if the difference is physiologically significant, it should also be statistically significant by one or more of the conventional criteria.
}

each subject, as indicated by an average value of $\mathrm{U}_{\mathrm{Na}} \mathrm{V}$ for all 30 basal periods of $161 \mu \mathrm{Eq}$. per minute, as compared with $160 \mu \mathrm{Eq}$. per minute for the 10 periods immediately preceding NPB. More significance can therefore be attached to changes in $\mathrm{U}_{\mathrm{Na}} \mathrm{V}$ associated with $\mathrm{NPB}$ than to the absolute values of this term.

When an increase in $\mathrm{U}_{\mathrm{Na}} \mathrm{V}$ was coincident with an increase in $\mathrm{C}_{\mathrm{H}_{2} \mathrm{O}}$ (R.R., E.B. and V.H.), the former undoubtedly reflects dead space error. In three subjects (C.S., V.D. and I.D.), $\mathrm{U}_{\mathrm{Na}} \mathrm{V}$ increased in the absence of an increase in $\mathrm{C}_{\mathrm{H}_{2} \mathrm{O}}$; since the fraction of $U_{\text {osm }}$ supplied by $U_{N a}$ remained nearly constant, however, the increase in $\mathrm{U}_{\mathrm{Na}} \mathrm{V}$ (and $\mathrm{U}_{\mathrm{osm}} \mathrm{V}$ ) may be attributable to a slight increase in filtration rate (4).

Taking all observations, the changes in $\mathrm{U}_{\mathrm{Na}} \mathrm{V}$ ranged from -66 (R.P.) to +156 (I.D.) $\mu \mathrm{Eq}$. per minute, and algebraically averaged $+51 \mu \mathrm{Eq}$. per minute. This figure is not significant statistically $(p>0.05)$ and we conclude that NPB is without effect on sodium excretion in hydropenic normotensive subjects. This conclusion is in agreement with the studies of Sieker, Gauer and Henry (1), Surtshin, Hoeltzenbein and White (2), Boylan and Antkowiak (3) and Murdaugh, Sieker and Manfredi (4).

\section{Hypertensive subjects}

Table II gives our observations on 10 hypertensive subjects. (The data are treated in the same manner as are the control subjects.) Again a steady state in respect to $\mathrm{V}$ and $\mathrm{U}_{\mathrm{Na}} \mathrm{V}$ in the basal periods was achieved by our protocol, as shown by averages of $1.26 \mathrm{ml}$. per minute and 178 $\mu \mathrm{Eq}$. per minute in the 30 basal periods prior to $\mathrm{NPB}$, as compared with $1.28 \mathrm{ml}$. per minute and $177 \mu \mathrm{Eq}$. per minute in the 10 periods immediately preceding NPB.

Eight subjects responded to NPB by a substantial increase in V; only in three (M.S., H.W. and E.C.), however, did $\mathrm{C}_{\mathrm{H}_{2} \mathrm{O}}$ become positive, though the directional change was positive in three others (W.K., W.R. and D.W.). The average value of $\mathrm{C}_{\mathrm{H}_{2} \mathrm{O}}$ did not increase significantly (basal, -1.13 ; NPB, $-0.37 \mathrm{ml}$. per minute), but as

4 Plasma osmolality ( $\mathrm{P}_{\mathrm{osm}}$ ) did not change during $\mathrm{NPB}$ in any of our subjects, confirming Boylan and Antkowiak (3). 


\section{ESSENTIAL HYPERTENSION}

W.K. 44 YR WHTE MALE
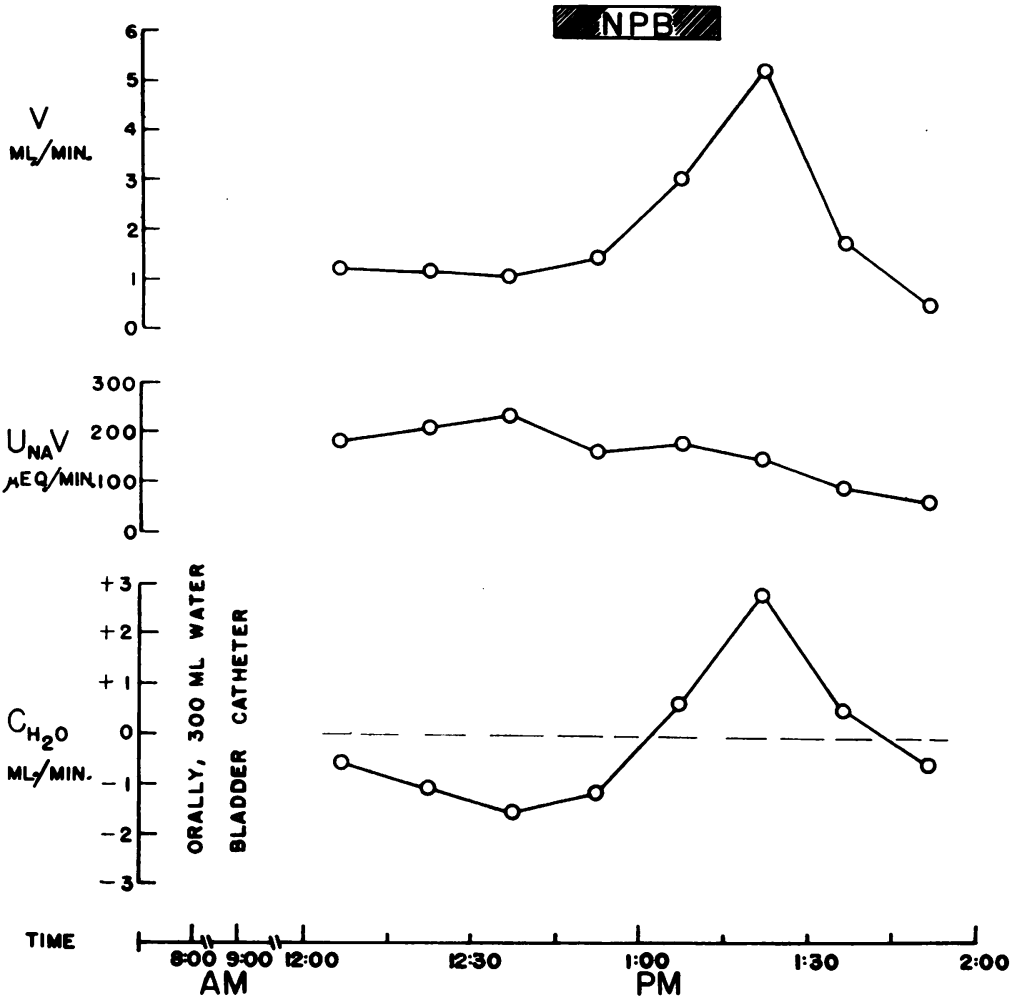

Fig. 1. NPB Following Moderate Hydration

noted above, in view of the hydropenic nature of our subjects this is less important than the qualitative fact that six out of 10 subjects gave an absolute or directionally positive change in this function. The diuretic effect of NPB appears to be as substantial in hydropenic hypertensive subjects as in normotensive subjects.

Basal sodium excretion again varied widely, from 61 to $558 \mu \mathrm{Eq}$. per minute. Maximal changes related to $\mathrm{NPB}$ ranged from -33 (W.K.) to $+270 \mu \mathrm{Eq}$. per minute (D.W.) and algebraically averaged $+86 \mu \mathrm{Eq}$. per minute, again a figure which is not statistically significant. We conclude that NPB has no natriuretic effect in hydropenic hypertensive subjects not explicable by dead space error.

Statistically, urine flow $(\mathrm{V}=+1.56 \mathrm{ml}$. per minute) was the only function in which the change was significant $(p<0.05)$, but again the component average terms, $\mathrm{C}_{\text {osm }}(+0.80 \mathrm{ml}$. per min- ute) and $\mathrm{C}_{\mathrm{H}, \mathrm{O} O}(+0.76 \mathrm{ml}$. per minute) did not separately show a significant increase $(p>0.05)$.

The importance of the state of hydration on the response to NPB is suggested by Figure 1, which shows a second test on W.K. who, as reported in Table II, gave only a barely significant response ( -1.39 to $-0.65 \mathrm{ml}$. $\mathrm{C}_{\mathrm{H}_{2} \mathrm{O}}$ per minute) in the hydropenic state. When tested four days later after moderate hydration ( $300 \mathrm{ml}$. water followed by $50 \mathrm{ml}$. every half hour), $\mathrm{C}_{\mathrm{H}_{2} \mathrm{O}}$ increased from -1.37 to $+2.75 \mathrm{ml}$. per minute. This response also indicates (as do our other data) that hypertensive subjects may be expected to respond to NPB as do normotensive subjects.

Contrariwise, the hazard of attributing natriuresis in a hypertensive subject to a particular stimulus is illustrated by Figure 2. D.B., a 56 year old white, female patient, was instructed to forego fluids from the night before the test. She came to the Research Unit at 8:00 a.m. and at 
$9: 30$ a.m. the urine flow was suspiciously high (2.33 ml. per minute). After interrogation she admitted having drunk coffee at $6: 30 \mathrm{a} . \mathrm{m}$. Whether attributable to the coffee, to catheterization, or to interrogation, she thereafter showed a natriuresis which at its peak reached $802 \mu \mathrm{Eq}$. per minute.

\section{Prehydrated normotensive subjects}

In contrast to the previous two groups, NPB induced a positive free water clearance in seven out of 10 prehydrated subjects (Table III); in these seven subjects, the increase in $\mathrm{C}_{\mathrm{H}_{2} \mathrm{O}}$ ranged from 1.30 to $7.12 \mathrm{ml}$. per minute. In two others (L.J. and S.B.), $\mathrm{C}_{\mathrm{H}_{2} \mathrm{O}}$ showed a directionally positive change, while one subject (A.B.) showed increased antidiuresis. The mean increase in $\mathrm{C}_{\mathrm{H}_{2} \mathrm{O}}$ for the nine subjects was $2.06 \mathrm{ml}$. per minute $(\mathrm{p}<0.01)$.
The increase in sodium excretion in these 10 prehydrated subjects ranged from 27 to $167 \mu \mathrm{Eq}$. per minute and averaged $80 \mu \mathrm{Eq}$. per minute; $\mathrm{C}_{\text {osm }}$ increased through the range of 0.05 to 1.79 $\mathrm{ml}$. per minute (average, $0.70 \mathrm{ml}$. per minute), in part because of increased $\mathrm{U}_{\mathrm{Na}} \mathrm{V}$ and possibly in part because of increased urea excretion. The average increase in $\mathrm{V}$ was $2.41 \mathrm{ml}$. per minute, reflecting increased $\mathrm{C}_{\mathrm{II} \bullet \mathrm{O}}(1.71 \mathrm{ml}$. per minute $)$ and $\mathrm{C}_{\text {osm }}(0.70 \mathrm{ml}$. per minute). All three terms $\left(+\Delta \mathrm{C}_{\mathrm{H}_{2} \mathrm{O}},+\Delta \mathrm{C}_{\mathrm{osm}}\right.$ and $\left.+\Delta \mathrm{V}\right)$ are statistically significant.

The average basal value of $\mathrm{U}_{\mathrm{Na}} \mathrm{V}$ in these subjects was $134 \mu \mathrm{Eq}$. per minute, the average peak value, $215 \mu \mathrm{Eq}$. per minute, figures which, excluding bicarbonate, represent only some 1 and 1.6 per cent, respectively, of the estimated filtered load of $\mathrm{NaCl}$ (102 mEq. per L. $\times 125 \mathrm{ml}$. per minute

\section{ESSENTIAL HYPERTENSION}

D.B. 56 YR WHITE FEMALE
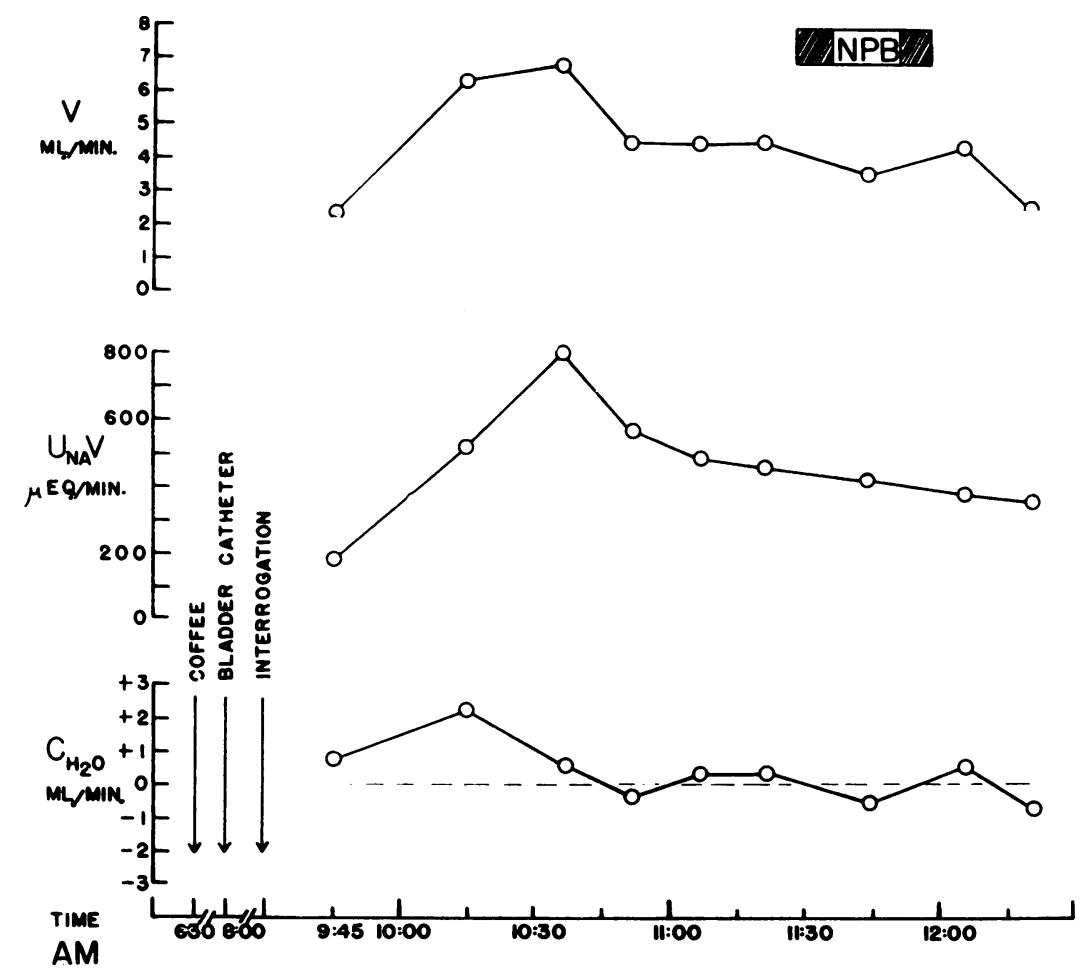

Fig. 2. Spontaneous Natriuresis in a Hypertensive Patient

The relative large urine flow at 9:30 a.m. suggested moderate hydration. The subject admitted to prior ingestion of coffee. 
or $12.7 \mathrm{mEq}$. per minute). We believe that an increase in $\mathrm{U}_{\mathrm{Na}} \mathrm{V}$ of this magnitude is most likely the unavoidable consequence of dead space error related to the increase in $\mathrm{C}_{\mathrm{H}_{2} \mathrm{O}}$. (The transience of the diuretic action of NPB precludes studies of $\mathrm{U}_{\mathrm{Na}} \mathrm{V}$ at a constant rate of urine flow.) For this reason we conclude that, in contrast to the effect of prehydration in facilitating the water diuresis produced by NPB, prehydration does not predispose the subject to natriuresis under this stimulus.

Thus the diuretic and natriuretic phenomena discussed elsewhere (21) may be dissociated with respect to excitatory stimuli. The diuretic effect of NPB is demonstrable in hydropenic hypertensive subjects and it is exaggerated (or facilitated) in prehydrated normotensive subjects who are also in the hydropenic state, but in neither group does NPB induce a natriuretic response. The afferent pathways from the Henry-Gauer reflex may be envisioned as communicating with the neurohypophyseal centers which mediate water diuresis, but apparently they do not communicate with neural centers having to do with natriuresis.

Subordinately, it is of interest to note that our basal values for control, hypertensive, and prehydrated subjects are very similar, as is shown at the bottom of Table III.

\section{SUMMARY AND CONCLUSIONS}

1. The effect of negative pressure breathing (NPB) on sodium, total solute and water excretion was observed in hydropenic normotensive subjects, hydropenic hypertensive subjects and normotensive subjects who had been prehydrated by water loading eight to nine hours before NPB.

2. Normotensive and hypertensive subjects responded to NPB with increased urine flow primarily because of increased free water clearance $\left(\mathrm{C}_{\mathrm{H}_{2} \mathrm{O}}\right)$. The increments observed in osmolal clearance $\left(\mathrm{C}_{\mathrm{osm}}\right)$ may be attributable to "washout" of urea in consequence of increased urine flow. Significant increases in sodium excretion did not occur.

3. NPB in prehydrated subjects induced a substantial increase in free water clearance, though at the time of NPB the subjects were in an antidiuretic state comparable to hydropenic nonprehydrated subjects. The small increase in sodium excretion can be explained by dead space error.
4. It is concluded that, under the conditions of this study, NPB is not a stimulus that leads to excessive natriuresis in subjects (hypertensive and prehydrated) otherwise predisposed to natriuresis.

\section{ACKNOWLEDGMENT}

The authors are grateful to Judy Oroszlan for technical assistance in this study.

\section{REFERENCES}

1. Sieker, H. O., Gauer, O. H., and Henry, J. P. The effect of continuous negative pressure breathing on water and electrolyte excretion by the human kidney. J. clin. Invest. 1954, 33, 572.

2. Surtshin, A., Hoeltzenbein, J., and White, H. L. Some effects of negative pressure breathing on urine excretion. Amer. J. Physiol. 1955, 180, 612.

3. Boylan, J. W., and Antkowiak, D. E. Mechanism of diuresis during negative pressure breathing. $\mathrm{J}$. appl. Physiol. 1959, 14, 116.

4. Murdaugh, H. V., Jr., Sieker, H. O., and Manfredi, F. Effect of altered intrathoracic pressure on renal hemodynamics, electrolyte excretion and water clearance. J. clin. Invest. 1959, 38, 834.

5. Miles, B. E., and De Wardener, H. E. Effect of emotion on renal function. Lancet 1953, 265, 539.

6. Brodsky, W. A., and Graubarth, H. N. Excretion of water and electrolytes in patients with essential hypertension. J. Lab. clin. Med. 1953, 41, 43.

7. Green, D. M., Wedell, H. G., Wald, M. H., and Learned, B. The relation of water and sodium excretion to blood pressure in human subjects. Circulation 1952, 6, 919.

8. Birchall, R., Tuthill, S. W., Jacobs, W. S., Trautman, W. J., Jr., and Findley, T. Renal excretion of water, sodium and chloride. Comparison of the responses of hypertensive patients with those of normal subjects, patients with specific adrenal or pituitary defects, and a normal subject primed with various hormones. Circulation 1953, 7, 258.

9. Cottier, P. T., Weller, J. M., and Hoobler, S. W. Effect of an intravenous sodium chloride load on renal hemodynamics and electrolyte excretion in essential hypertension. Circulation 1958, 17, 750.

10. Baldwin, D. S., Biggs, A. W., Goldring, W., Hulet, W. H., and Chasis, H. Exaggerated natriuresis in essential hypertension. Amer. J. Med. 1958, 24, 893.

11. Hanenson, I. B., Taussky, H. H., Polasky, N., Ransohoff, W., and Miller, B. F. Renal excretion of sodium in arterial hypertension. Circulation 1958, 18, 733.

12. Ek, J. The influence of heavy hydration on the renal function in normal and hypertensive man. Scand. J. clin. Lab. Invest. 1955, 7, suppl. 19.

13. Ladd, M. Renal excretion of sodium and water in man as affected by prehydration, saline infusion, 
pitressin and thiomerin. J. appl. Physiol. 1952, 4, 602 .

14. Johlin, J. M. The freezing-point determination of physiological solutions. The usual errors and their elimination. J. biol. Chem. 1931, 91, 551.

15. Bowman, R. L., Trantham, H. V., and Caulfield, P. A. An instrument and method for rapid, dependable determination of freezing-point depression. J. Lab. clin. Med. 1954, 43, 310.

16. Snedecor, G. W. Statistical Methods, 5th ed. Ames, Iowa, Iowa State College Press, 1956.

17. Mainland, D. A Synopsis with Subtraction, Addition and Other Changes of Elementary Statistics: The Principles of Quantitative Medicine. New York,
Department of Medical Statistics, New York University College of Medicine, 1957.

18. Smith, H. W. Renal excretion of sodium and water. Fed. Proc. 1952, 11, 701.

19. Wesson, L. G., Jr., and Anslow, W. P., Jr. Effect of osmotic and mercurial diuresis on simultaneous water diuresis. Amer. J. Physiol. 1952, 170, 255.

20. Zak, G. A., Brun, C., and Smith, H. W. The mechanism of formation of osmotically concentrated urine during the antidiuretic state. J. clin. Invest. 1954, 33, 1064.

21. Smith, H. W. Salt and water volume receptors. An exercise in physiologic apologetics. Amer. J. Med. 1957, 23, 623 . 